University of Warwick institutional repository: http://go.warwick.ac.uk/wrap This paper is made available online in accordance with publisher policies. Please scroll down to view the document itself. Please refer to the repository record for this item and our policy information available from the repository home page for further information.

To see the final version of this paper please visit the publisher's website. Access to the published version may require a subscription.

Author(s): Helen M. GROGAN and Richard H. GAZE Article Title: Fungicide resistance among Cladobotryum spp. - causal agents of cobweb disease of the edible mushroom Agaricus bisporus Year of publication: 2000 Link to published version: http://dx.doi.org/10.1017/S0953756299001197

Publisher statement: None 


\title{
Fungicide resistance among Cladobotryum spp. - causal agents of cobweb disease of the edible mushroom Agaricus bisporus
}

\author{
Helen M. GROGAN and Richard H. GAZE \\ Department of Plant Pathology and Microbiology, Horticulture Research International, Wellesbourne, Warwick CV35 9EF, UK. \\ Accepted 14 May 1999.
}

\begin{abstract}
A survey of fungicide resistance among isolates of the mushroom pathogens Cladobotryum mycophilum and C. dendroides Types I and II was undertaken, with respect to the active ingredients thiabendazole, carbendazim (benzimidazoles) and prochloraz manganese following an epidemic in Britain and Ireland in 1994/95. The majority of isolates (41/57) were strongly resistant to thiabendazole $\left(\mathrm{ED}_{50}>200 \mathrm{ppm}\right)$ and were exclusively $C$. dendroides Type II. All C. mycophilum and C. dendroides Type I isolates, and four $C$. dendroides Type II isolates, were weakly resistant to thiabendazole ( $\left.\mathrm{ED}_{50} 1-10 \mathrm{ppm}\right)$. Thiabendazole-resistant $C$. dendroides Type II isolates were only weakly resistant to carbendazim $\left(\mathrm{ED}_{50} 2-10 \mathrm{ppm}\right)$ and isolates which were weakly resistant to thiabendazole were carbendazim-sensitive $\left(\mathrm{ED}_{50}<1 \mathrm{ppm}\right)$, demonstrating a lack of complete cross resistance between these two benzimidazole fungicides. The $\mathrm{ED}_{50}$ values for all isolates with respect to prochloraz manganese ranged from 0.14 to $7.8 \mathrm{ppm}$. Benzimidazole resistance was considered to have been an important factor influencing the severity of the $1994 / 95$ cobweb epidemic but $25 \%$ of isolates collected were benzimidazole sensitive.
\end{abstract}

Cladobotryum dendroides is more commonly known in the mushroom industry by its synonym, Dactylium dendroides, or as its teleomorph Hypomyces rosellus. It is responsible for the mushroom disease known as cobweb (Fletcher, White \& Gaze, 1989). It produces a verticillately branched conidiophore bearing two-, three- and four-celled conidia. Colonies on mushroom casing are usually circular in appearance and can rapidly engulf adjacent mushrooms, causing rapid decay. Massive sporulation usually occurs once mushrooms are encountered and the dry spores, which are easily dislodged when watering the mushroom crop, are responsible for a brown spotting symptom on mushroom fruit bodies. Other Cladobotryum species have been recorded from cultivated mushrooms by various authors and include C. multiseptatum, C. mycophilum, C. varium (syn. C. variospermum) and C. verticillatum (Sinden, 1971; De Hoog, 1978; Sharma, Suman \& Guleria, 1992). A number of Hypomyces spp. with Cladobotryum anamorphs have been isolated from members of the Aphyllophorales and Agaricales growing in the wild (Rogerson \& Samuels, 1993, 1994). Some of these produce conidia and conidiophores which are similar to $C$. dendroides so it is possible that some unusual Cladobotryum species may occur on commercial mushrooms.

Outbreaks of cobweb disease on British mushroom farms were sporadic for many years with the disease being controlled using available fungicides (Fletcher et al., 1989). In the early 1990s outbreaks became more frequent, and reached epidemic proportions in 1994/95. Although fungicide resistance was implicated, outbreaks of cobweb were already on the increase, and it was suggested that the warmer and moister environments in which mushrooms are now grown, compared with the early 1980s, may have been a contributory factor to the emergence of cobweb (Gaze, 1995). In the 1970s resistance to benzimidazole fungicides had developed in Verticillium fungicola, another mushroom pathogen, and a survey of 229 U.K. isolates indicated that $53 \%$ had $\mathrm{ED}_{50}$ values of $>50 \mathrm{ppm}$ with respect to the fungicide benomyl (Fletcher \& Yarham, 1976). This 1970s survey also reported that, of 24 Cladobotryum isolates tested, none grew at $5 \mathrm{ppm}$ benomyl (or 1 ppm where tested), indicating that isolates were still sensitive to this fungicide. In the British mushroom industry benomyl has been largely replaced by the active ingredient carbendazim, which is a major primary breakdown product of benomyl (Hassall, 1990), and would be expected to have similar activity as benomyl against individual pathogens. Fletcher \& Yarham (1976) demonstrated this for $10 \mathrm{~V}$. fungicola isolates. In the 1980s benomyl, thiabendazole (and prochloraz manganese) were still effective against an isolate of Cladobotryum in a cropping experiment (Fletcher, Hims \& Hall, 1983). In the same year, Lockley \& Gay (1983) reported that an isolate from a farm using thiabendazole was capable of 15 and $0 \%$ growth at 50 and $100 \mathrm{ppm}$ thiabendazole, respectively, while isolates from two other farms failed to grow at thiabendazole concentrations of $25 \mathrm{ppm}$ or above $\left(\mathrm{ED}_{50}\right.$ values for all isolates were $\leqslant 10 \mathrm{ppm}$ ). In a later survey of 12 British farms in 1993, 14 Cladobotryum isolates from one farm were capable of growth at 2 and $20 \mathrm{ppm}$ thiabendazole $\left(\mathrm{ED}_{50}\right.$ not given), but only one of these isolates grew at 2 ppm 
benomyl, which led the authors to conclude that resistance to thiabendazole but not benomyl had occurred on this one farm (Fletcher \& Jaffe, 1993). These data confirm that some Cladobotryum isolates from British farms were capable of growth at 50 or 20 ppm thiabendazole in 1983 and 1993, respectively, but, in the absence of detailed baseline data, it is difficult to draw any firm conclusions as to whether isolates were becoming resistant; these observations may have simply reflected normal variation in the background level of sensitivity to benzimidazole fungicides within the Cladobotryum population as a whole. A survey was, therefore, undertaken to reexamine, in more detail, the resistance status of Cladobotryum isolates in Britain.

\section{MATERIALS AND METHODS}

\section{Fungicides}

Commercial formulations of the three most commonly used fungicides in the British mushroom industry were used in this study (Table 1). Thiabendazole and carbendazim are both benzimidazole fungicides which bind to fungal beta-tubulins and inhibit microtubule function. Prochloraz manganese is a sterol C-14 demethylation inhibitor which impairs biosynthesis of ergosterol, an essential compound for the stability and functioning of lipoprotein membranes (Hassall, 1990). Freshlymade stock solutions were prepared to give specific concentrations of active ingredient in ppm. Volumes of stock solution were added to molten $\left(50^{\circ} \mathrm{C}\right)$ sterile culture media prior to pouring giving active ingredient concentrations ranging from 0.01 to $500 \mathrm{ppm}$ depending on the experiment.

\section{Isolates}

Fifty-seven Cladobotryum isolates were screened (Table 2) of which 51 were obtained from various mushroom farms in Britain (England, Scotland and Wales). The remaining isolates were obtained from France (3), Northern Ireland (2) and the Republic of Ireland (1). Of the British isolates, 35 were obtained as single isolates from individual farms, five farms provided two isolates each and two farms provided three isolates each, giving a total of 42 farms. Isolate $5 \mathrm{~A}$ was obtained in 1993 while all remaining isolates were obtained during 1995. All isolates were placed in the HRI culture collection in liquid nitrogen and were maintained on $2 \%$ malt agar slopes at $4^{\circ}$ during the experimental period. Selected isolates were sent to IMI, Egham, Surrey, U.K. for identification.

\section{Determination of fungicide activity against mycelial growth in vitro}

Fungicide activity against mycelial growth in vitro was determined for each isolate with respect to the three fungicides thiabendazole, carbendazim and prochloraz manganese. Isolates were grown on malt extract agar (MEA, Oxoid, Basingstoke, England) in which active ingredients were incorporated at concentrations of $0,1,2,10,20$ and 50 ppm. Three replicate Petri dishes were prepared for each isolate at each concentration of each active ingredient. Petri dishes were inoculated with a $5 \mathrm{~mm}$ diam. plug of mycelium which was taken from the growing edge of a 2-4 d old culture. Inoculum plugs were placed $10 \mathrm{~mm}$ in from the edge of a $90 \mathrm{~mm}$ diam. Petri dish and incubated at $25^{\circ}$. Radial growth across the Petri dish was measured daily. A daily radial growth rate $\left(\mathrm{mm} \mathrm{d}^{-1}\right)$ was calculated using data from the linear phase, usually between days $2-4$ or 3-7, depending on how fast individual isolates grew. When growth was slow, particularly on media containing high concentrations of fungicides, radial growth rate was calculated based on measurements taken at 3-7 d intervals over a period of 14 or $21 \mathrm{~d}$. Growth response curves were then prepared for each isolate with respect to each of the three active ingredients by plotting radial growth rate against fungicide concentration. An $\mathrm{ED}_{50}$ category (i.e. the concentration range within which the linear growth rate was reduced by $50 \%$ ) was assigned to each isolate for each active ingredient. Isolates were tested in groups of 5-10 as they were received from growers during the period from February to August 1995.

When all initial tests were completed, 13 isolates were selected for repeat testing but the range of concentrations used was extended based on the results from the initial tests. Thus, thiabendazole concentrations ranged from 1 to $500 \mathrm{ppm}$; carbendazim concentrations ranged from 0.01 to $64 \mathrm{ppm}$ and prochloraz manganese concentrations ranged from 0.01 to $100 \mathrm{ppm} . \mathrm{ED}_{50}$ values were calculated for each isolate using two methods. For each of three replicate concentration series, the concentration which gave a $50 \%$ reduction in colony

Table 1. Details of three fungicide active ingredients used in mushroom crop protection.

\begin{tabular}{|c|c|c|c|}
\hline & \multicolumn{3}{|c|}{ Fungicide active ingredient (a.i.) } \\
\hline & Thiabendazole & Carbendazim & Prochloraz manganese \\
\hline Trade name & Hymush $^{1}$ & Bavistin & Sporgon \\
\hline Formulation (\% a.i.) & $60 \% \mathrm{WP}$ & $50 \% \mathrm{WG}$ & $46 \% \mathrm{WP}$ \\
\hline Supplier & Agrichem & BASF & Darmycel (Agrevo) \\
\hline Standard dose ${ }^{2}$ (g product $\mathrm{m}^{-2}$ ) & 2.0 & 2.5 & $1.2(\times 2)$ \\
\hline g a.i. $\mathrm{m}^{-2}(\simeq 50 \mathrm{l}$ casing $)$ & 1.2 & 1.25 & $0.55(\times 2)$ \\
\hline $\begin{array}{l}\text { Concentration in casing } \\
\text { mg a.i. } \mathrm{kg}^{-1} \text { casing (ppm) }\end{array}$ & 34.2 & 35.7 & $15.5(\times 2)$ \\
\hline
\end{tabular}

\footnotetext{
1 No longer available for use on mushrooms in Britain.

2 Refer to product labels for full details of fungicide application rates.

3 Based on an average casing bulk density of $700 \mathrm{~g} \mathrm{l}^{-1}$ and product uniformily mixed throughout.
} 
Table 2. Characteristics of 57 Cladobotryum isolates from the UK, Republic of Ireland and France.

\begin{tabular}{|c|c|c|c|c|c|c|}
\hline & \multirow[b]{2}{*}{ Origin } & \multirow{2}{*}{$\begin{array}{l}\text { Conidial } \\
\text { cell } \\
\text { number }\end{array}$} & \multirow{2}{*}{$\begin{array}{l}\text { Camphor } \\
\text { odour }\end{array}$} & \multirow{2}{*}{$\begin{array}{l}\text { Radial } \\
\text { growth rate } \\
\left(\mathrm{mm} \mathrm{d}^{-1}\right)\end{array}$} & \multicolumn{2}{|l|}{$\mathrm{ED}_{50}(\mathrm{ppm})$} \\
\hline & & & & & Thiabendazole & Carbendazim \\
\hline \multicolumn{7}{|c|}{ Weakly resistant to thiabendazole ${ }^{1}$} \\
\hline \multicolumn{7}{|c|}{ C. mycophilum } \\
\hline 192B3 & W. Sussex & $1,2(3)$ & Yes & 11.0 & $1-2$ & $<1$ \\
\hline $202 \mathrm{~A}^{2}$ & Kent & $1,2(3,4)$ & Yes & 12.4 & $1-2$ & $<1$ \\
\hline 202B & Kent & 1,2 & Yes & 13.1 & $1-2$ & $<1$ \\
\hline $220 \mathrm{D}$ & France & 1,2 & Slight & 11.0 & $2-10$ & $<1$ \\
\hline 222 & Wiltshire & 1,2 & Yes & 12.8 & $2-10$ & $<1$ \\
\hline $241 C^{2}$ & E. Lothian & $1,2,(3,4)$ & Yes & 19.3 & $1-2$ & $<1$ \\
\hline 257 & Kent & $1,2(3)$ & Yes & 13.1 & $1-2$ & $<1$ \\
\hline \multicolumn{7}{|c|}{ C. dendroides Type I } \\
\hline 187 & W. Sussex & $(1,2) 3,4$ & No & 13.0 & $2-10$ & $<1$ \\
\hline $195 \mathrm{~A}$ & Devon & $2,3,4$ & No & 14.8 & $2-10$ & $<1$ \\
\hline $220 \mathrm{~B}$ & France & $(1,2) 3,4$ & No & 12.9 & $1-2$ & $<1$ \\
\hline 289 & Devon & $2,3,4(5,6)$ & No & 16.0 & $2-10$ & $<1$ \\
\hline \multicolumn{7}{|c|}{ C. dendroides Type II } \\
\hline $193 \mathrm{~A}$ & Suffolk & $1,2,3,4$ & No & 20.0 & $2-10$ & $<1$ \\
\hline $193 B$ & Suffolk & $1,2,3,4$ & No & 23.1 & $1-2$ & $<1$ \\
\hline $193 C$ & Suffolk & $1,2,3,4$ & No & 20.2 & $2-10$ & $<1$ \\
\hline $220 \mathrm{C}$ & France & $1,2,3,4$ & No & 21.5 & $1-2$ & $<1$ \\
\hline \multicolumn{7}{|c|}{$\begin{array}{l}\text { Strongly resistant to thiabendazole } \\
\text { C. dendroides Type II }\end{array}$} \\
\hline $5 \mathrm{~A}^{3}$ & Lancashire & $1,2,3,4$ & No & 21.0 & $>50$ & $2-10$ \\
\hline 164 & Worcestershire & $1,2,3,4$ & No & 22.0 & $>50$ & $2-10$ \\
\hline 165 & Worcestershire & $1,2,3,4$ & No & 22.3 & $>50$ & $2-10$ \\
\hline 166 & Hampshire & $1,2,3,4$ & No & 19.9 & $>50$ & $2-10$ \\
\hline 167 & Hampshire & $1,2,3,4$ & No & 18.2 & $>50$ & $2-10$ \\
\hline 169 & Republic of Ireland & $1,2,3,4$ & No & 21.3 & $>50$ & $2-10$ \\
\hline 174 & Dorset & $1,2,3,4$ & No & 21.2 & $>50$ & $2-10$ \\
\hline 176 & Dorset & $1,2,3,4$ & No & 19.0 & $>50$ & $2-10$ \\
\hline $192 \mathrm{~A}(6 \mathrm{a})$ & W. Sussex & $1,2,3,4$ & No & 20.3 & $>50$ & $2-10$ \\
\hline 192A(D6a) & W. Sussex & $1,2,3,4$ & No & 21.8 & $>50$ & $2-10$ \\
\hline $192 \mathrm{BI}^{3}$ & W. Sussex & $1,2,3,4$ & No & 20.8 & $>50$ & $2-10$ \\
\hline $192 \mathrm{C}$ & W. Sussex & $1,2,3,4$ & No & 19.6 & $>50$ & $2-10$ \\
\hline $192 C(6 a)$ & W. Sussex & $1,2,3,4$ & No & 21.2 & $>50$ & $2-10$ \\
\hline $196 \mathrm{~A}$ & Devon & $1,2,3,4$ & No & 22.0 & $>50$ & $2-10$ \\
\hline 209 & Hampshire & $1,2,3,4$ & No & 21.5 & $>50$ & $2-10$ \\
\hline 213 & N. Yorkshire & $1,2,3,4$ & No & 20.0 & $>50$ & $2-10$ \\
\hline 214 & Devon & $1,2,3,4$ & No & 19.8 & $>50$ & $2-10$ \\
\hline $215 \mathrm{~A}$ & Fife & $1,2,3,4$ & No & 19.4 & $>50$ & $2-10$ \\
\hline $215 B$ & Fife & $1,2,3,4$ & No & 20.6 & $>50$ & $2-10$ \\
\hline $217 \mathrm{~A}$ & E. Lothian & $1,2,3,4$ & No & 20.8 & $>50$ & $2-10$ \\
\hline $217 \mathrm{~B}$ & E. Lothian & $1,2,3,4$ & No & 20.8 & $>50$ & $2-10$ \\
\hline $217 \mathrm{C}$ & E. Lothian & $1,2,3,4$ & No & 22.2 & $>50$ & $2-10$ \\
\hline $229 B$ & W. Sussex & $1,2,3,4$ & No & 20.7 & $>50$ & $2-10$ \\
\hline $229 \mathrm{C}$ & W. Sussex & $1,2,3,4$ & No & 19.0 & $>50$ & $2-10$ \\
\hline 231 & Derbyshire & $1,2,3,4$ & No & 20.3 & $>50$ & $2-10$ \\
\hline $232 \mathrm{~B}$ & Shropshire & $1,2,3,4$ & No & 21.3 & $>50$ & $2-10$ \\
\hline 235 & Norfolk & $1,2,3,4$ & No & 21.8 & $>50$ & $2-10$ \\
\hline 239 & Surrey & $1,2,3,4$ & No & 19.5 & $>50$ & $2-10$ \\
\hline 240 & Fife & $1,2,3,4$ & No & 19.5 & $>50$ & $2-10$ \\
\hline $243 B$ & Strathclyde & $1,2,3,4$ & No & 20.0 & $>50$ & $2-10$ \\
\hline 245 & Northern Ireland & $1,2,3,4$ & No & 20.0 & $>50$ & $2-10$ \\
\hline $247 B$ & Northumberland & $1,2,3,4$ & No & 20.2 & $>50$ & $2-10$ \\
\hline $249 \mathrm{C}$ & Lancashire & $1,2,3,4$ & No & 19.7 & $>50$ & $2-10$ \\
\hline $260 \mathrm{~A}$ & W. Sussex & $1,2,3,4$ & No & 21.7 & $>50$ & $2-10$ \\
\hline 273 & Northern Ireland & $1,2,3,4$ & No & 20.5 & $>50$ & $2-10$ \\
\hline 281 & Buckinghamshire & $1,2,3,4$ & No & 20.5 & $>50$ & $2-10$ \\
\hline 288 & Oxfordshire & $1,2,3,4$ & No & 20.0 & $>50$ & $2-10$ \\
\hline 297 & M. Glamorgan & $1,2,3,4$ & No & 19.2 & $>50$ & $2-10$ \\
\hline 298 & S. Humberside & $1,2,3,4$ & No & 19.7 & $>50$ & $2-10$ \\
\hline
\end{tabular}

1 Each number represents an individual farm except for 192A, B and C and 193A, B and C which represent three individual farm units within two larger farm complexes, and also $220 \mathrm{~B}, \mathrm{C}$ and D which are from different French farms.

2 Isolates identified by CABI Bioscience as C. mycophilum.

3 Isolates identified by CABI Bioscience as C. dendroides. 
radius after $3 \mathrm{~d}$ incubation was calculated by linear interpolation (Method I). ED 50 values were also calculated for each isolate using radial growth rate data collected over a 2 wk period (Method II).

\section{RESULTS}

\section{Isolate characterization}

Selected isolates which were sent to IMI for identification were confirmed as either C. mycophilum (Oudem.) W. Gams \& Hooz.: isolates 202A (IMI 372796) and 241C (IMI 368694) or C. dendroides (Bull. Fr.) W. Gams \& Hooz.: isolates 5A (IMI 359310) and 192BI (IMI 372795). The conida and

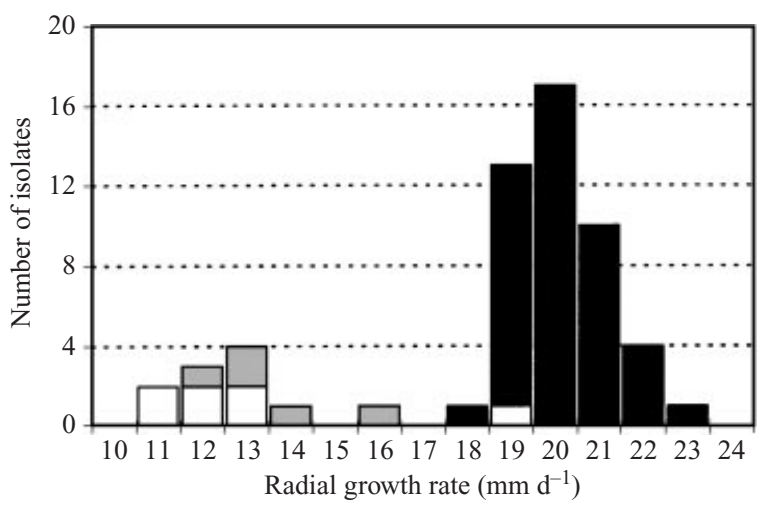

Fig. 1. Frequency distribution of radial growth rate for 57 Cladobotryum isolates; $\square$, C. mycophilum; 國, C. dendroides Type I and $\boldsymbol{\square}, \mathrm{C}$. dendroides Type II. conidiogenous cells of C. mycophilum isolates were similar to the descriptions given by Gams \& Hoozemans (1970) and Cole \& Kendrick (1971) for this species. C. dendroides isolates were divided into two groups according to the nature of the conidiogenous cells. In Type I isolates the conidiogenous cells extended irregularly as a result of successive sympodial spore production and were similar to the description given for this species by Gams \& Hoozemans (1970). The conidiogenous cells of Type II isolates, which included two isolates identified by IMI as $C$. dendroides, did not produce an irregularly shaped extending tip as described by Gams \& Hoozemans (1970); they ranged from being relatively long with narrow apices to relatively short with wide apices and were similar to the description and diagrams by Cole \& Kendrick (1971) for C. mycophilum, except that a greater number of three- and fourcelled conidia were produced. The two types of isolates also differed in their radial growth rate with Type I isolates growing more slowly than Type II isolates.

Following the initial processing of the 57 isolates there appeared to be two distinct groups in terms of growth on MEA at $25^{\circ}$ (Fig. 1). All C. mycophilum isolates (apart from 241C) and all $C$. dendroides Type I isolates had a radial growth rate of between 11 and $16 \mathrm{~mm} \mathrm{~d}^{-1}$ with an average of 13.2 , and $14.0 \mathrm{~mm} \mathrm{~d}^{-1}$ (s.E.M. $=1.07$, and 0.61), respectively. One C. mycophilum isolate $(241 \mathrm{C})$ had a faster, more variable radial growth rate of $16.5-20 \mathrm{~mm} \mathrm{~d}^{-1}$. All C. dendroides Type II isolates had a radial growth rate of $18.2-23.1 \mathrm{~mm} \mathrm{~d}^{-1}$ with an average for the group of $20.5 \mathrm{~mm} \mathrm{~d}^{-1}$ (s.E.M. $=0.15$ ). C. dendroides Type II isolates accounted for 45 out of 57 isolates examined of which 41 were from Britain, three were from Ireland and one was from France. Isolates of C. mycophilum

Table 3. Radial growth rate at $25^{\circ}$ and $\mathrm{ED}_{50}$ values of fungicides for selected Cladobotryum isolates.

\begin{tabular}{|c|c|c|c|c|c|}
\hline & \multirow{3}{*}{$\begin{array}{l}\text { Radial } \\
\text { growth } \\
\text { rate } \\
\left(\mathrm{mm} \mathrm{d}^{-1}\right)\end{array}$} & \multicolumn{4}{|c|}{$\mathrm{ED}_{50}$ values $(\mathrm{ppm})$} \\
\hline & & \multirow{2}{*}{$\begin{array}{l}\text { Thiabendazole } \\
\text { Method I* }\end{array}$} & \multirow{2}{*}{$\begin{array}{l}\text { Carbendazim } \\
\text { Method I }\end{array}$} & \multicolumn{2}{|l|}{ Prochloraz } \\
\hline & & & & Method I & Method II† \\
\hline \multicolumn{6}{|l|}{ C. mycophilum } \\
\hline $220 \mathrm{D}$ & 13.8 & 1.9 & $(-1.13) \neq 0.32$ & 0.33 & 0.19 \\
\hline 222 & 11.3 & 3.4 & $(-0.87) 0.42$ & 0.34 & 0.73 \\
\hline $241 \mathrm{C}$ & 18.5 & 2.5 & $(-0.89) 0.41$ & 0.18 & 0.14 \\
\hline \multicolumn{6}{|c|}{ C. dendroides Type I } \\
\hline $195 \mathrm{~A}$ & 12.1 & 1.9 & $(-1.49) 0.22$ & 0.46 & 4.2 \\
\hline $220 \mathrm{~B}$ & 13.6 & 1.5 & $(-1.43) 0.24$ & 0.85 & 7.8 \\
\hline \multicolumn{6}{|c|}{ C. dendroides Type II } \\
\hline 169 & 19.8 & $>500$ & (1.25) 3.8 & 0.56 & 3.7 \\
\hline 192B1 & 20.8 & $>500$ & (1.43) 4.2 & 0.62 & 3.5 \\
\hline 213 & 20.7 & $>500$ & (1.25) 3.5 & 0.63 & 2.4 \\
\hline 214 & 21.2 & $>500$ & (1.33) 3.8 & 0.36 & 1.5 \\
\hline 215 & 19.7 & 207 & (1.26) 3.5 & 0.74 & 2.2 \\
\hline 239 & 20.8 & 221 & (1.48) 4.4 & 0.52 & 1.1 \\
\hline 245 & 21.2 & $>500$ & (1.47) 4.3 & 0.56 & 1.8 \\
\hline $193 \mathrm{~A}$ & 20.5 & 1.2 & $(-1.37) 0.25$ & 0.38 & 0.54 \\
\hline S.E.M. ( 26 d.f.) & 0.67 & $23.3 \S$ & $(0.082)$ & 0.118 & 0.545 \\
\hline L.S.D. $(P=0.05)$ & 1.37 & 47 & $(0.16)$ & 0.24 & 1.12 \\
\hline
\end{tabular}

\footnotetext{
* Method I: $\mathrm{ED}_{50}$ calculated after $3 \mathrm{~d}$ growth

+ Method II: $\mathrm{ED}_{50}$ calculated using radial growth rate data.

₹ $\log _{n}$-transformed data.

$\S$ ANOVA carried out on data for eight isolates with $\mathrm{ED}_{50}$ values $<500$, s.E.M., d.f. $=16$.
} 


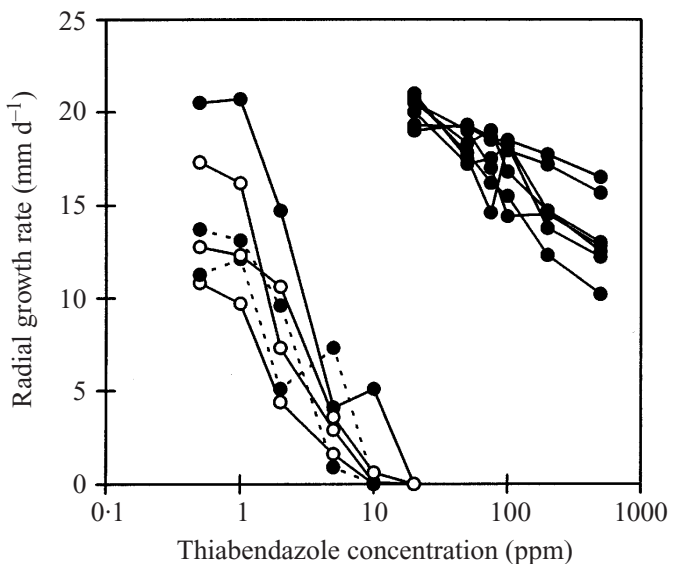

Fig. 2. Growth response curves of Cladobotryum isolates to thiabendazole: $-\bigcirc-$, C. mycophilum; -- --, C. dendroides Type I; - - C. dendroides Type II.

and $C$. dendroides Type I accounted for the remaining 12 isolates examined, of which 10 were from Britain and two were from France. With one exception (isolates 192BI and 192B3), different isolates obtained from the same farm were all similar to each other.

\section{Fungicide resistance profiles in vitro}

Thiabendazole. All C. mycophilum, C. dendroides Type I and four C. dendroides Type II isolates (193A, 193B, 193C and 220C) demonstrated an ability to tolerate thiabendazole at low concentrations. They were capable of good growth at 1 and 2 ppm but most isolates were severely inhibited at concentrations of $10 \mathrm{ppm}$ or above. $\mathrm{ED}_{50}$ values were between 1-2 or 2-10 ppm (Table 2). Repeat tests on selected isolates indicated that $\mathrm{ED}_{50}$ values ranged from 1.2 to $3.4 \mathrm{ppm}$ (Table 3 ) and growth response curves were similar (Fig. 2), but they reflected differences in the radial growth rates of each isolate in the absence of any fungicide. These isolates, which were severely inhibited at $10 \mathrm{ppm}$ thiabendazole, are thus considered to be weakly resistant to thiabendazole. The remaining 41 isolates, all $C$. dendroides Type II, were strongly resistant to thiabendazole with $\mathrm{ED}_{50}$ values of $>50 \mathrm{ppm}$. Repeat testing indicated that most had an $\mathrm{ED}_{50}>500 \mathrm{ppm}$ (Table 3) and growth response curves were similar (Fig. 2). $E_{50}$ determination using either radial growth after $3 \mathrm{~d}$ (Table 3 ) or radial growth rate (data not shown) gave similar results.

Carbendazim. The 41 strongly-thiabendazole-resistant $C$. dendroides Type II isolates all demonstrated some ability to tolerate carbendazim. They were capable of good growth at 1 and 2 ppm but were severely inhibited at $10 \mathrm{ppm}$ and above. $\mathrm{ED}_{50}$ values were between 2 and 10 ppm (Table 2). Repeat tests indicated that $\mathrm{ED}_{50}$ values ranged from 3.5 to $4.4 \mathrm{ppm}$ (Table 3 ) and growth response curves were similar (Fig. 3). These isolates were considered to be weakly resistant to carbendazim. All C. mycophilum, C. dendroides Type I, and the four Type II isolates which were weakly resistant to thiabendazole, were very sensitive to carbendazim with $\mathrm{ED}_{50}$ values of $<1$ ppm. Repeat tests indicated that $\mathrm{ED}_{50}$ values ranged from 0.22 to $0.42 \mathrm{ppm}$. Growth response curves were

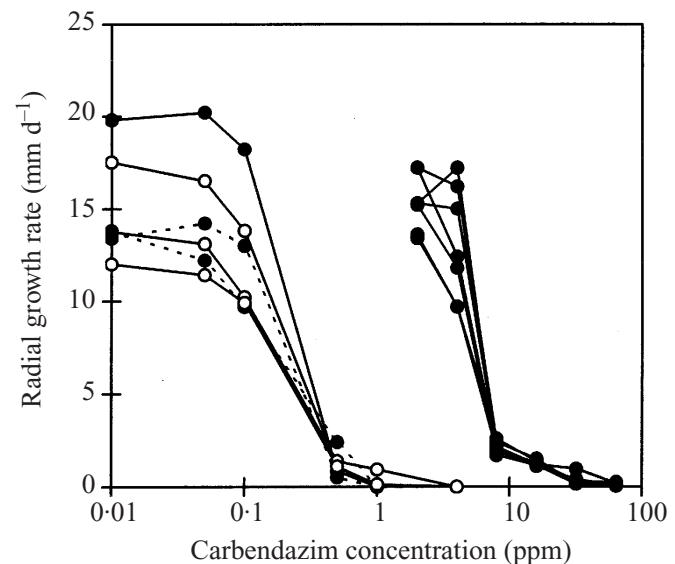

Fig. 3. Growth response curves of Cladobotryum isolates to carbendazim: - $\bigcirc-$, C. mycophilum;-- --, C. dendroides Type I; - - C. dendroides Type II.

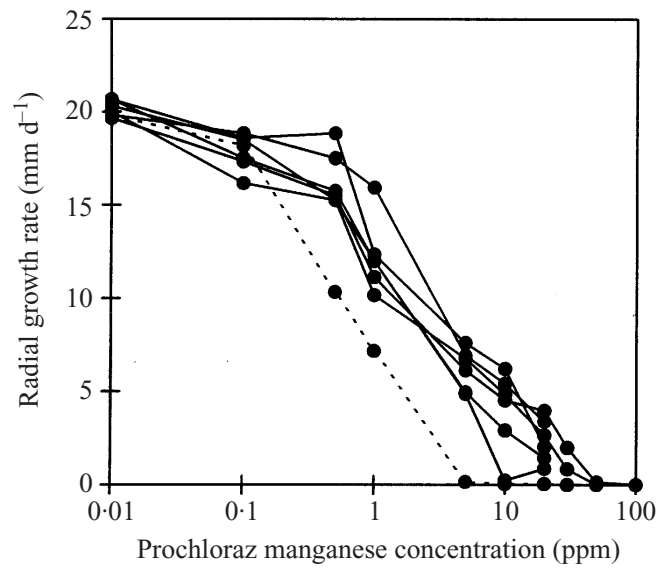

Fig. 4. Growth response curves of $C$. dendroides Type II isolates to prochloraz manganese. - - strongly resistant to thiabendazole; --- weakly resistant to thiabendazole.

similar (Fig. 3) but reflected differences in control growth rates. $\mathrm{ED}_{50}$ determination using either radial growth after $3 \mathrm{~d}$ (Table 3 ) or radial growth rate (data not shown) gave similar results.

Prochloraz manganese. The response of all isolates to prochloraz manganese in the initial tests, carried out over a period of time, was variable with no clear patterns emerging (data not shown) unlike the responses to the two benzimidazole fungicides. A selected number of isolates from each species group were re-tested together to minimise variation. This entailed using a single batch of media, a single preparation of fungicide, and inoculum plugs taken from fresh cultures with a uniform growing edge. On this occasion, the stronglythiabendazole-resistant $C$. dendroides Type II isolates all gave very similar response curves (Fig. 4) while the weakly resistant isolates were more variable (Figs 4,5). A repeat experiment confirmed these results. The $\mathrm{ED}_{50}$ values for prochloraz manganese differed depending on how it was calculated (Table 3 ). When radial growth after $3 \mathrm{~d}$ was used, all $\mathrm{ED}_{50}$ values were $<1 \mathrm{ppm}$, ranging from 0.18 to 0.85 , whereas when radial growth rate data were used (collected over a $2 \mathrm{wk}$ period), $\mathrm{ED}_{50}$ values ranged from 0.14 to 7.8 . There was a 


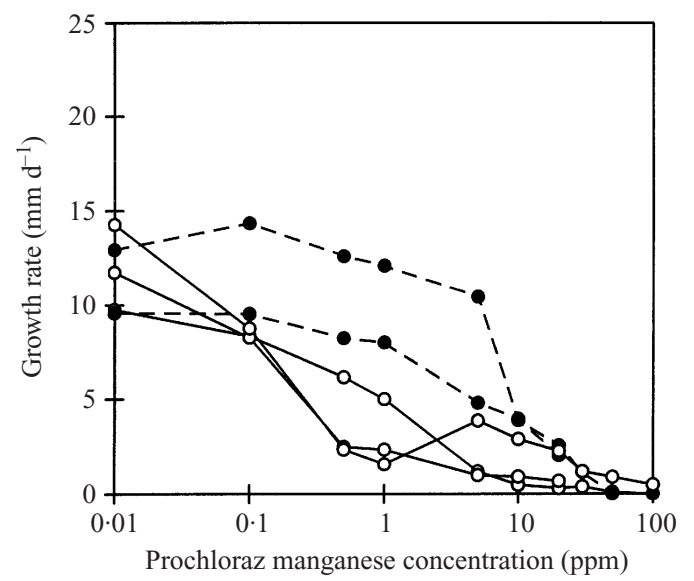

Fig. 5. Growth response curves of Cladobotryum isolates to prochloraz manganese: - $\bigcirc-$, C. mycophilum; -- --, C. dendroides Type I (all weakly resistant to thiabendazole).

significant correlation $(P=0.01)$ between the two sets of values with $r=0.77$ (95\% confidence limits $=0.37,0.93$ ) indicating that $41 \%\left(1-r^{2} \times 100\right)$ of the variation between the two methods was unexplained. This is likely to reflect the fact that zero growth was recorded after $3 \mathrm{~d}$ at higher prochloraz manganese concentrations whereas radial growth rate, calculated after 2 wk growth, gave significantly fewer zero values.

\section{DISCUSSION}

Cladobotryum dendroides Types I and II and C. mycophilum were isolated from mushroom farms around Britain during the height of a cobweb epidemic in 1995. Isolates of $C$. dendroides Types I and II produced many three- and four-celled conidia but differences in conidiophore morphology warranted separating them into two groups. McKay et al. (1999) have recently reported on genetic characterization of Cladobotryum species which included C. dendroides Type II isolates 192BI and 213 and C. mycophilum isolates 202A, 222, and 241C (Table 2), and which are listed by them as isolates numbers 87 , $89,88,90$ and 91, respectively. They demonstrated that isolates from Britain and Ireland associated with the 1993-5 epidemic, and initially identified as $C$. dendroides, were genetically more similar to C. mycophilum than to a $C$. dendroides isolate from the U.S.A. which was identified by W. Gams (CBS, The Netherlands) as $C$. dendroides. The conidiogenous cells of this U.S.A. isolate produced a secondary extension (similar to the Type I isolates reported here) while their other ' $C$. dendroides' isolates did not. Based on the genetic data, they have concluded that the ' $C$. dendroides' isolates associated with the epidemic form a distinct subgroup (subgroup 2) within the C. mycophilum species group. McKay et al. (1999) recorded no morphological differences between their C. mycophilum subgroups 1, 2 and 3 but we have separated subgroup 2 (isolates 192B1 and 213) from subgroups 1 and 3 based on conidia cell number, presence or absence of a camphor odour and radial growth rate at $25^{\circ}$ (Table 2). We have not found morphological data to separate C. mycophilum subgroup 1 (isolates 202A and 241C) from subgroup 3 (isolate 222). The genetic data of McKay et al. (1999) clearly indicate a closer relationship between these taxa. Rogerson \& Samuels (1994) record that the teleomorphs of C. mycophilum (H. odoratus) and $C$. dendroides ( $H$. rosellus) are identical and that they differ only in their anamorphic forms. Attempted crosses between single ascospore isolates taken from perithecia of $H$. odoratus or $H$. rosellus failed to produce any perithecia while crosses between single ascospore isolates within each species were successful. Mating interactions between selected isolates in Table 2 are currently being carried out to investigate the relationship between $C$. mycophilum and $C$. dendroides Types I and II in the light of the genetic information provided by McKay et al. (1999). Descriptions of C. mycophilum by Gams \& Hoozemans (1970), De Hoog (1978) and Rogerson \& Samuels (1994), do not indicate that three- and four-celled conidia are a feature of this species although the diagram of Cole \& Kendrick (1971) includes them. Three- and four-celled conidia have been observed in many of the C. mycophilum isolates examined in this study but they were not the most common, and for some isolates were very rare. Further investigation is necessary to determine the critical morphological characteristics of these two species in relation to their genetic characterization.

Of the 51 British Cladobotryum isolates collected during the height of the cobweb epidemic in 1995, 25\% were weakly resistant to thiabendazole $\left(E_{50} 1-10 \mathrm{ppm}\right)$, sensitive to carbendazim $\left(\mathrm{ED}_{50}<1 \mathrm{ppm}\right)$ and showed a variable range of responses to prochloraz manganese ( $\mathrm{ED}_{50}$ 0.19-7.8 ppm). These isolates included all C. mycophilum and $C$. dendroides Type I isolates and three $C$. dendroides Type II isolates. The remaining $75 \%$ of British isolates were all strongly resistant to thiabendazole $\left(\mathrm{ED}_{50}>200 \mathrm{ppm}\right)$, weakly resistant to carbendazim ( $\left.\mathrm{ED}_{50} \quad 3.5-4.4 \mathrm{ppm}\right)$ and weakly resistant to prochloraz manganese $\left(\mathrm{ED}_{50} 1.1-3.7 \mathrm{ppm}\right)$, and all were identified as $C$. dendroides Type II. These results suggest that the 'thiabendazole-resistant' isolate of Lockely \& Gay (1983) was not the same as the thiabendazole-resistant $C$. dendroides Type II isolates reported here, as it was incapable of growth at $100 \mathrm{ppm}$ thiabendazole, whereas the thiabendazole-resistant C. dendroides Type II isolates associated with the cobweb epidemic grew very well at this concentration. The 'thiabendazole-resistant' isolate from one farm described by Fletcher \& Jaffe (1993) may have been a C. dendroides Type II isolate as it was capable of growth at $20 \mathrm{ppm}$ thiabendazole and 2 ppm benomyl. No data were presented for growth at higher concentrations of thiabendazole, so it is difficult to comment with certainty on the nature of the observed resistance. Most of the thiabendazole-weakly-resistant isolates in this survey failed to grow at $20 \mathrm{ppm}$ thiabendazole or I ppm carbendazim ( $=1.5 \mathrm{ppm}$ benomyl approx.), so there is a good chance the isolate described by Fletcher \& Jaffe (1993) was similar to a thiabendazole-resistant $C$. dendroides Type II. Three thiabendazole-weakly-resistant isolates in this survey had growth rates of $25 \%$ or less at 20 ppm thiabendazole and this suggests that there may be some wild isolates which are more tolerant to thiabendazole or that some mutations do not give rise to high levels of resistance. It is important, therefore, to test a pathogen's response to a wide range of fungicide concentrations in order to determine more precisely the degree of resistance present. Thiabendazole, carbendazim and 
benomyl (structurally and functionally very similar to carbendazim) are benzimidazole fungicides whose mode of action is interference with the division of cell nuclei by disrupting the assembly of tubulin into microtubules (Hassalls, 1990). Cross resistance to these chemicals often occurs and has been demonstrated for the mushroom pathogen $V$. fungicola which is highly resistant to thiabendazole and benomyl (Bonnen \& Hopkins, 1997). The molecular structure of thiabendazole is, however, sufficiently different from that of benomyl and carbendazim to imply that their abilities to bind to tubulin may differ (Hassalls, 1990). Differences in benzimidazole sensitivity have been shown to reflect differences in the (beta-tubulin gene) mutations which confer resistance (Davidse, 1986; Fujimura et al., 1990) so that a mutation which leads to poor binding of, and therefore resistance to, thiabendazole may not necessarily affect the binding of carbendazim to the same extent. This scenario could describe the pattern of resistance recorded for $C$. dendroides Type II isolates. Bonnen \& Hopkins (1997) also reported that $12 \%$ of $V$. fungicola isolates tested were not cross resistant to both thiabendazole and benomyl indicating that at least two different mutation sites may have been involved. McKay et al. (1998) have recently shown that benzimidazole resistance in $C$. dendroides isolates from Ireland is caused by a single base transition mutation at codon 50 , causing an amino acid substitution from TAC (tyrosine) to TGC (cysteine). This location had not previously been recorded as being associated with benzimidazole resistance in field isolates of pathogens. The three thiabendazole-resistant Irish isolates in Table 2, 169, 245 and 273, were all classified as $C$. dendroides Type II, so there is a possibility that the mutation conferring benzimidazole resistance to all $C$. dendroides Type II isolates in Table 2 is the same as that described by McKay et al. (1998). It would appear, therefore, that this mutation has a greater inhibitory effect on the binding of thiabendazole compared with carbendazim. Of interest, also, is the fact that no C. mycophilum or C. dendroides Type I isolates were thiabendazole-resistant and this may suggest that the structure of their tubulin is different from that of $C$. dendroides Type II.

C. dendroides Type II appears to represent Cladobotryum isolates which have recently developed benzimidazole resistance, since a previous survey found only one farm with a thiabendazole-resistant strain (Fletcher \& Jaffe, 1993). This may have occurred as a result of regular use of benzimidazole fungicides to control other mushroom pathogens and this phenomenon is widely recognized following benzimidazole use (Hassall, 1990; Bonnen \& Hopkins, 1997). Under more stringent experimental conditions, however, C. dendroides Type II responses to prochloraz manganese were very similar to each other, unlike the responses of $C$. dendroides Type I and C. mycophilum isolates, and this finding suggests that the $C$. dendroides Type II isolates may be clonal in nature. All C. dendroides Type I and C. mycophilum isolates, and a few $C$. dendroides Type II isolates, were much more sensitive to both carbendazim and thiabendazole, and had more variable responses to prochloraz manganese so these may represent sensitive wild-type isolates. Such isolates represented $25 \%$ of British isolates received during this survey at the height of the
1994-5 epidemic which suggests that, despite their sensitivity to benzimidazoles, they were nonetheless associated with serious incidences of cobweb. This in turn suggests that although resistance to benzimidazole fungicides probably made control of cobweb more difficult, there may have been an underlying increase in the incidence of cobweb (Gaze, 1995, 1997). Work is in progress to identify cultural factors which may influence the epidemiology of $C$. dendroides.

The concentration of thiabendazole and carbendazim in casing following application of a standard commercial dose is in the region of $35 \mathrm{ppm}$ (Table 1 ) although concentrations are likely to be higher in the surface layers of the casing following a drench application. Most $C$. dendroides Type II isolates have an $\mathrm{ED}_{50}>200 \mathrm{ppm}$ for thiabendazole so it is unlikely that this fungicide would control outbreaks of cobweb caused by such isolates. Isolates which are only weakly-resistant to thiabendazole, however, with $\mathrm{ED}_{50}$ values of $<10 \mathrm{ppm}$, such as C. mycophilum and C. dendroides Type I may well be controlled by this fungicide. Carbendazim might be expected to be very effective against $C$. mycophilum and $C$. dendroides Type I isolates $\left(E_{50}<1 \mathrm{ppm}\right)$ but probably less effective against most $C$. dendroides Type II isolates $\left(\mathrm{ED}_{50}<10 \mathrm{ppm}\right)$.

The fungicide resistance profile of individual mushroom pathogens gives good information on whether or not a given fungicide will be effective in controlling a disease outbreak. With the evolution of strongly, or even weakly, resistant isolates, the efficacy of fungicides may be significantly compromized. It is important, however, to determine exactly what role fungicide resistance plays in the loss of disease control by a fungicide, as there are complex interactions between fungicide resistance, fungicide persistence in mushroom casing and on-farm disease management, in addition to the effects of growing conditions and environment. Work is ongoing in this area to understand the relative importance of individual factors.

\section{ACKNOWLEDGEMENTS}

Financial support from the Horticultural Development Council (Project M14a) is gratefully acknowledged. We would like to thank Mrs Anita Scruby for technical support, Dr J. M. Olivier for providing French isolates and Dr Liam Staunton for providing Irish isolate 167.

\section{REFERENCES}

Bonnen, A. M. \& Hopkins, C. (1997). Fungicide resistance and population variation in Verticillium fungicola, a pathogen of the button mushroom, Agaricus bisporus. Mycological Research 101, 89-96.

Cole, G. T. \& Kendrick, B. (1971). Conidium ontogeny in hyphomycetes. Development and morphology of Cladobotryum. Canadian Journal of Botany 49, 595-599.

Davidse, L. C. (1986). Benzimidazole fungicides: mechanism of action and biological impact. Annual Revue of Phytopathology 24, 43-65.

De Hoog, G. S. (1978). Notes on some fungicolus hyphomycetes and their relatives. Persoonia 10, 33-81.

Fujimura, M., Oeda, K., Inoue, H. \& Kato, T. (1990). Mechanism of action of $\mathrm{N}$-phenylcarbamates in benzimidazole-resistant Neurospora strains. In Managing Resistance to Agrochemicals, ACS Symposium Series 421 (ed. M. B. Green, H. M. LeBaron \& W. K. Moberg), pp. 224-236. American Chemical Society: Washington, DC, U.S.A.

Fletcher, J. T., Hims, M. J. \& Hall, R. J. (1983). The control of bubble diseases and cobweb disease of mushrooms with prochloraz. Plant Pathology 32, 123-131. 
Fletcher, J. T. \& Jaffe, B. (1993). Mushrooms - fungicide resistance. Horticultural Development Council Research Report M/14: Bradbourne House, East Malling, Kent, ME19 6DZ, U.K.

Fletcher, J. T., White, P. F. \& Gaze, R. H. (1989). Mushrooms: Pest and Disease Control. 2nd edn. Intercept: Andover, Hants., U.K.

Fletcher, J. T. \& Yarham, D. J. (1976). The incidence of benomyl tolerance in Verticillium fungicola, Mycogone perniciosa and Hypomyces rosellus in mushroom crops. Annals of Applied Biology 84, 343-353.

Gams, W. \& Hoozemans, X. (1970). Cladobotryum-Konidienformen von Hypomyces-Arten. Persoonia 6, 99-110.

Gaze, R. H. (1995). The problem page: Dactylium or Cobweb. The Mushroom Journal 546, 23-24.

Gaze, R. H. (1997). The problem page: Dactylium - prudence or heroics. The Mushroom Journal 565, 18-19.

Hassall, K. A. (1990). The Biochemistry and Uses of Pesticides. 2nd edn. VCH Weinheim: New York, Basle, Cambridge.

Lockely, K. D. \& Gay, C. (1983). Differential sensitivity to benzimidazole fungicides in strains of Hypomyces rosellus. Plant Pathologists Technical
Conference 1983, PPT/798. Ministry of Agriculture, Fisheries and Food, Agricultural Development and Advisory Service, Agricultural Science Service: Bristol, England.

McKay, G. J., Egan, D., Morris, E. \& Brown, A. E. (1998). Identification of benzimidazole resistance in Cladobotryum dendroides using a PCR-based method. Mycological Research 102, 671-676.

McKay, G. J., Egan, D., Morris, E., Scott, C. \& Brown, A. E. (1999). Genetic and morphological characterization of Cladobotryum species causing cobweb disease of mushrooms. Applied and Environmental Microbiology 65, 606-610.

Rogerson, C. T. \& Samuels, G. J. (1993). Polyporicolous species of Hypomyces. Mycologia 85, 231-272.

Rogerson, C. T. \& Samuels, G. J. (1994). Agaricicolous species of Hypomyces. Mycologia 86, 839-866.

Sharma, V. P., Suman, B. C. \& Guleria, D. S. (1992). Cladobotryum verticillatum - a new pathogen of Agaricus bitorquis (Quél.) Sacc. Indian Journal of Mycology and Plant Pathology 22, 62-65.

Sinden, J. W. (1971). Ecological control of pathogens and weed moulds in mushroom culture. Annual Review of Phytopathology 9, 411-432. 